\title{
Smart Building Integration into a Smart City (SBISC): Development of a New Evaluation Framework
}

\author{
Rasa Apanaviciene ${ }^{1, *}$, Andrius Vanagas ${ }^{1}$ and Paris A. Fokaides ${ }^{1,2, *}$ (i) \\ 1 Faculty of Civil Engineering and Architecture, Kaunas University of Technology, Studentu str. 48, \\ LT-51367 Kaunas, Lithuania; vanagasand@gmail.com \\ 2 School of Engineering, Frederick University, Nicosia 1036, Cyprus \\ * Correspondence: rasa.apanaviciene@ktu.lt (R.A.); eng.fp@frederick.ac.cy (P.A.F.)
}

Received: 23 March 2020; Accepted: 19 April 2020; Published: 1 May 2020

\begin{abstract}
The aim of this study is to define the features that smart buildings should fulfil in order to be compatible with the overall context of the smart city and to introduce a new evaluation framework of Smart Buildings Integration into a Smart City (SBISC). By analysing scientific literature as well as existing international and local project examples, the features of smart buildings that are expected to be adopted in smart cities were identified. The SBISC evaluation methodology was developed and applied to a set of selected projects. The literature review revealed that the smart building and smart city concepts were developed in different time frames and by different stakeholders and, thus, need to be realigned. The most important aspect is to employ in a smart building all the functionalities proposed by the smart areas of the city and vice versa by enabling the recommended features of smart materials, smart building services, and smart construction to serve for the surrounding systems. Nine office buildings representing smart building concept in different smart cities built within the period $2007-2018$ with a total area from $10,000 \mathrm{~m}^{2}$ to $143,000 \mathrm{~m}^{2}$ were selected for the analysis. The research of selected projects revealed that the smart buildings have more potential to become smarter by utilizing smart cities capabilities in the areas of smart energy, smart mobility, smart life, and smart environment. Smart cities are the most prominent trend in creating a cohesive environment.
\end{abstract}

Keywords: smart city; smart buildings; ICT; interoperability; sustainability

\section{Introduction}

According to the 2018 Revision of World Urbanization Prospects report, 55\% of the world's population lives in urban areas, and the percentage is expected to reach $68 \%$ by 2050 [1]. The world's cities are built on just $3 \%$ of the Earth's land but consume $60 \%-80 \%$ of the global energy and produce $75 \%$ of the total carbon emissions [2]. Cities face major challenges in maintaining a sustainable environment and a healthy lifestyle, considering the growing population, required infrastructure, increasing resources demand, waste management, and the required services that need to be developed [3].

The concept of a smart city is the brightest contemporary trend integrating the ideas of smart mobility, smart economy, smart people, smart government, smart environment, and smart living. The construction sector plays an important role in adapting to the new challenges in all these areas. Buildings and infrastructure need to be built and operated in accordance with smart city features. Thus, the terms "smart building" and "smart city" are widely discussed by researchers, industry professionals, the community, and representatives at the city and higher governance levels. The EU policy focuses on developing ISO standards of certain smart city areas [4], the funding of smart cities lighthouse projects [5], and on financial incentives for smart buildings and smart city elements [6].

Smart buildings are considered to be one of the major elements of the built environment within a smart city. The first smart building definition was published in 1989 by the Intelligent Building Institute 
of the United States. A smart building was described as providing an efficient environment through optimized structures, systems, services and management, and the interrelationships between them. Later on, the impact on the operational efficiency, effectiveness of its occupants, and employment of information and communication technologies (ICTs) were emphasized [7,8]. Smart cities, the operational efficiency of which is heavily dependent on buildings, are the most prominent trend in creating a cohesive environment of the future [9]. However, there are no particular recommendations on how the new materials and technologies should be applied to the construction projects in smart cities. Therefore, it is important to investigate what features would be the most critical in adapting future buildings to the digital smart city platform. It comes as no surprise that there is a need to identify the integration requirements that construction projects have to meet in order to be consistent with the overall context of a smart city.

The latest challenges of the advanced development of smart buildings and smart city are related to digitalisation: compliance of the buildings with the new city ecosystem, adaptability to the environment, information collection and transmission, real-time information communication, information management, and action control [10-12]. A lot of attention needs to be paid to the development of a new approach based on the combination of two individual fields that describes the main principles of smart building integration into a smart city. Thus, the aim of this study is to develop a new evaluation framework of "Smart Building Integration into a Smart City" (SBISC).

\section{Smart City and Smart Building: Concept Evolution}

In this section, the major features of smart cities and smart buildings are described. The analysis is performed on a literature overview basis. A review of smart building and smart city assessment is also performed.

\subsection{Smart City}

The concept of a smart city has been changing over the time from "intelligent" to "digital" to "smart" and to "sustainable smart" or "smart sustainable"; many different definitions and main dimensions of a smart city have been identified without unified consensus through a literature review [7-9,12]. Giffender et al. [13] defined the required components of a smart city, and Lombardi et al. [14] defined the related aspects of urban life for each one of these components (Table 1).

Table 1. Smart city components (adapted from Lombardi et al. [14]).

\begin{tabular}{cc}
\hline Component of A Smart City & Related Aspect of Urban Life \\
\hline Smart Economy & Industry, Innovation, and Competitiveness \\
Smart People & Education Creativity, and Social Capital \\
Smart Governance & E-democracy, Participation, and Empowerment \\
Smart Mobility & Logistics and Infrastructures, Transportation \\
Smart Environment & Efficiency and Sustainability, Resources \\
Smart Living & Security and Quality, Culture \\
\hline
\end{tabular}

In 2015, three generations of smart cities were introduced by Professor Boyd Cohen as "three distinct phases of how cities have embraced technology and development, moving tech company driven, to city government driver, to, finally, citizen drive" (Smart Cities 1.0: Technology Driven; Smart Cities 2.0: Technology Enabled, City-Led; Smart Cities 3.0: Citizen Co-Creation) [15]. Smart Cities 1.0 might be characterized as single-stand different technologies solutions for city control without analysing the overall application impact on citizen well-being. Smart Cities 2.0 emphasize the role of the implementation of smart technologies and other innovations in facilitating industry growth and higher quality of public services for citizens and visitors. In Smart Cities 3.0, citizen co-creation models attract people to collaborate with the municipality and apply the benefits of recent digital platforms 
and technologies by transforming the city, creating new information, projects, services and businesses, and flourishing co-working and co-sharing culture for a better quality of life and urban ecosystem.

Applying modern ICT technologies tends to ensure the fulfilment of the needs of current and future generations and responds to the challenges associated with innovations, efficiency, and competitiveness of public services and urban structure. The latest UNECE definition highlights smart and sustainability city concepts integration: "A smart sustainable city is an innovative city that uses Information and Communication Technologies (ICT) and other means to improve quality of life, efficiency of urban operation and services, and competitiveness, while ensuring that it meets the needs of present and future generations with respect to economic, social, environmental as well as cultural aspects" [16].

The rapid development of new technologies is shaping the smart cities of the future. The set of technologies for building the smart cities of the future was recently described by Fourtane [17]: $5 \mathrm{G}$ technologies, sensors, the Internet of Things (IoT), geospatial technology including geographic information systems (GIS) and global positioning systems (GPS), artificial intelligence (AI), robotics, virtual reality (VR), augmented reality (AR), and blockchain technology.

According to Fourtané, "smart and sustainable city urban planning affects everyone, and it's crucial to know and understand what the technologies involved in building smart cities are and how they can help achieve the ultimate goal of urban transformation into the truly smart cities of the future". The same technologies ensure the full integration of smart buildings into the smart city platform.

\subsection{Smart Building}

According to the study of the United Nations (UN) Environment Programme, buildings at a global level utilise about $40 \%$ of energy, $25 \%$ of water, $40 \%$ of resources, and emit about $33 \%$ of GHG emissions; residential and commercial buildings use about $60 \%$ of the world's electricity [18]. The tendencies of building design and construction have historically changed in a way that is similar to the development path of a smart city: from energy efficient to sustainable, to green, to intelligent, and finally to smart [19]. In 1989, the Intelligent Building Institute of the United States described an intelligent building as providing a productive and cost-effective environment through the optimisation of structures, systems, services, and management, as well as the interrelationships between them. In 1998, the European Intelligent Building Group stated that an intelligent building "creates the environment that maximizes the effectiveness of its occupants, while at the same time enables the efficient management of resources with minimum life-time costs of hardware and facilities" [7]. The advancement of ICT has led the expansion of the smart buildings market and the change in the smart building concept. According to the European Commission, "Smart buildings means buildings empowered by ICT in the context of the merging Ubiquitous Computing and the Internet of Things: the generalisation in instrumenting buildings with sensors, actuators, micro-chips, micro- and nano-embedded systems will allow to collect, filter and produce more and more information locally, to be further consolidated and managed globally according to business functions and services" [20]. Based on a recent forecast, the global smart buildings market is expected to demonstrate a compound annual growth rate (CAGR) of $32 \%$, reaching $\$ 43$ billion USD by 2022 [21].

The concept of a smart building is being developed at all stages of the building life cycle, focusing on the design, construction, and operational phases. In many cases, a smart building combines the characteristics of a sustainable building and a green building. Smart buildings are usually confused with zero energy buildings [22] or passive buildings [23], which are not the same things as smart buildings. At the design stage, when the building's digital model is developed, the energy efficiency of the future building is simulated and analysed, considering the location and orientation, urban infrastructure, and other environmental conditions using the latest and most effective technological solutions of building materials and products, building services, and construction processes based on ICT. It is estimated that about $10 \%$ of a building's whole $\mathrm{CO}_{2}$ emissions originates from the building materials production, and $15 \%$ of total $\mathrm{CO}_{2}$ emissions during the construction process is caused by the lack of a smart logistics approach [20]. Therefore, these are the areas of expected progress in smart 
building construction: eco-friendly construction materials; effective organization of logistics processes, sharing best practice between ICT, energy, and construction sector organisations; and a transparent collaborative environment for architects, engineers, clients, operators, and other stakeholders.

The operation stage of a smart building can be defined as the most advanced automated process, enabling different building services to interact with each other. Different sensors and controllers may regulate the performance of different systems, such as heating, air conditioning, ventilation, lighting, security, water, etc. This reduces energy consumption, to increase safety and security as well as to improve personal indoor comfort for the occupants. The smart building learns from the experience to make the most efficient real-time decisions in order to maximize comfort and productivity at the lowest energy costs. Implementing smart building solutions can reduce up to $30 \%$ of water and up to $40 \%$ of energy usage and save from $10 \%$ to $30 \%$ on costs of overall building maintenance [20].

In summary, both smart cities and smart buildings serve the people inside the buildings and inside the city, providing them with more rational and personalized solutions, making their lives easier in terms of economic, environmental, social, and cultural aspects. Analysing the role of a smart building alone, it might be stated that the smart building's management system as a local data management centre can adopt a building's behaviour based on the changing environment inside or outside of the building. When the smart buildings are interconnected into a smart city network, the smart building itself can impact the behaviour of the other smart buildings or infrastructure because it becomes a consistent outside environment element influencing the other elements of the network. The smart city data platform receives and shares all the data from the interconnected elements in the network. Based on the communication between the local and central data platforms, the most efficient decisions can be made in favour of the occupants of a particular building as well as inhabitants of the city.

\subsection{Review of Smart Building and Smart City Assessment Schemes}

Several assessment schemes for smart buildings and smart cities have been released in the past few years. This section refers to the following assessment schemes:

- $\quad$ The Building Intelligent Quotient (BiQ);

- $\quad$ The Honeywell Smart Building Score (HSBS);

- $\quad$ The evaluation for smart buildings presented by Omar [24];

- $\quad$ The EU Smart Readiness Indicator (SRI) scheme;

- The smart city assessment scheme presented by Sharifi [25].

Concerning smart buildings, they can be evaluated by defining how well the various systems communicate; how the usage data is collected, analysed, and applied to building performance; and how well the technologies respond to the various input devices. In 2005, an online tool called the Building Intelligent Quotient (BiQ) with over 300 questions to rate the building's intelligence level was introduced by the Continental Automated Buildings Association (CABA). The BiQ guides on the design for the following issues that are considered to be relevant when selecting intelligent building components suitable for linking into a building automation network [26]:

- Building structure and systems;

- Building automation and security systems;

- Building communication systems;

- Building and facility management applications.

The Honeywell Smart Building Score ${ }^{\mathrm{TM}}$ (HSBS) was introduced in 2015 and has been applied worldwide for smart buildings assessment. It is based on 15 technology assets with three main impact criteria—green, safe, and productive (Table 2). 
Table 2. The Honeywell Smart Building Score ${ }^{\mathrm{TM}} 2.0$ components (adapted from reference [27]).

\begin{tabular}{ccc}
\hline Green & Safe & Productive \\
\hline Energy sources & Security-people, vehicle, material & Indoor air and water quality \\
Utility sources & Fire safety & Circulation-people, vehicle, material \\
Temperature control & Gas safety & Personalization \\
Electricity control & Worker safety & Connectivity \\
Utility control & Disaster response & Energy quality \\
\hline
\end{tabular}

Omar [24] stated that a diversity of aspects might be included for intelligent building evaluation. The author presented main evaluation criteria (intelligent skins, building automation system (BAS), building management system (BMS), sensors, smart materials, passive design technologies, and renewable resources) and 68 sub-factors for intelligent building design selection from an architectural point of view. On the other hand, eight quality condition components and sub-components were identified as primary criteria alongside the aspects of energy and environment, space flexibility, cost-effectiveness, client comfort, working efficiency, safety, culture, and technology. This approach enables the project team to ensure energy efficiency while providing supreme quality living standards.

The revised EU Energy Performance of Buildings Directive (EPBD) 2018/844 was updated with the new term "smart readiness indicator" (SRI) [28]. SRI calculation methodology for buildings was accomplished in 2018 under the authority of the European Commission DG Energy. SRI assesses the technological readiness of buildings based on their capabilities to interact with their occupants and the energy grids and to provide more efficient operation and optimized performance due to ICT employment [29]. SRI score presents a final result of a multi-criteria evaluation of smart readiness functionality levels of 52 building services from 10 main domains, which demonstrate the impact on eight categories (Table 3):

Table 3. Smart readiness indicator (SRI) domains and impact categories [29].

\begin{tabular}{ll}
\hline \multicolumn{1}{c}{ Domains of Building Services } & \multicolumn{1}{c}{ Impact Categories } \\
\hline - Heating & \\
- Domestic hot water & - Energy savings on site \\
- Cooling & - Flexibility for the grid and storage \\
- Controlled ventilation & - Self-generation, \\
- Lighting & - Comfort \\
- Dynamic building envelope & - Convenience, \\
- On-site renewable energy generation & - Wellbeing and health \\
- Demand side management & - Maintenance and fault prediction \\
- Electric vehicle charging & - Information to occupants \\
- Monitoring and control & \\
\hline
\end{tabular}

The SRI methodology is expected to be a great EU-wide tool for building readiness assessment to be performed in a "smart way" from energy efficiency perspective [30]. However, Janhunen et al. [31] noticed that "the baseline design for the European SRI is not directly feasible for cold climate countries and without any methodological changes in the framework, the SRI appears not to realize its original purpose as an equally applicable EU-wide energy efficiency activity".

The assessment of the smart city concept comprises many more domains compared to smart buildings. Based on the analysis of 34 existing smart city assessment schemes, Sharifi [25] presented a typology of smart city evaluation tools and indicator sets. The author concluded that different approaches have been selected for smart city assessment because there is no consensus on the definition of a smart city. The other identified reason might be variations related with the priorities of the developers and the needs of the end users. Despite these facts, the most frequently used themes and factors were identified (Table 4). 
Table 4. The most commonly used themes and factors [25].

\begin{tabular}{ll}
\hline Clustering Component & \multicolumn{1}{c}{ Most Commonly Used Items (listed in Descending Order of Frequency) } \\
\hline Themes & $\begin{array}{l}\text { Economy, environment, governance, mobility, living, people, data } \\
\text { Education, infrastructure, health, services, innovation, culture, transportation, } \\
\text { environment, inclusion, safety, governance, energy, business, pollution, planning, } \\
\text { entrepreneurship, sustainability, security, accessibility, water, resources, technology, } \\
\text { building, participation, social, efficiency, productivity, economy, connectivity, traffic, } \\
\text { employment, housing. }\end{array}$ \\
\hline
\end{tabular}

Within the list of seven themes and 32 identified factors, the majority of them might be associated with the components and performance of a smart building. Thus, considering this rationale, the development of a new evaluation framework of Smart Building Integration into a Smart City (SBISC) is presented in the next section.

\section{Smart Building Integration into a Smart City (SBISC): Development of a New Evaluation Framework}

In this section, the main aspects of smart building and smart city technologies are presented independently, based on previous scientific works and studies. The last section introduces the main principles of the proposed Smart Building Integration into a Smart City (SBISC) model, which is based on the combined approach of two individual fields.

\subsection{Smart Building Technologies}

The purpose of an intelligent system for building services is to create the conditions for the easy and efficient operation and management of residential and workplace areas, considering the immediate and ongoing needs of its occupants, by ensuring the long-term strategic goal of the owners in aspects such as comfort, safety, economy, energy efficiency, and representativeness. The Global Smart Building Market Research Report [32] emphasizes the following intelligent building services:

- Building energy management system (energy management system, heating, ventilations and air conditioning (HVAC) control system, lighting control system);

- Infrastructure management system (elevators and escalators management system, smart water management system, parking management system);

- Intelligent security system (video surveillance system, access control system, emergency management system);

- Network management system.

New technologies in construction enable developers to deliver complex projects in the most optimal manner. Technology-based ICT programs and tools change the way companies develop the project design, its planning, and its execution. Advanced software, hardware, and analytical tools eliminate problems that have stifled the construction sector for decades, including difficulties in project design and communication. These improvements have come to the market at the same time that construction projects are becoming more complex and expensive, and managers are anxious to reduce costs, meet deadlines, and improve efficiency. Real-time data capture and analytics of the condition of a construction site enable better environmental protection (site energy consumption and $\mathrm{CO}_{2}$ emissions), safety, operational efficiency, productivity, quality, and profitability at the construction site. Thus, the deployment of smart and sustainable building technologies becomes significantly important, and building professionals have demonstrated a strong awareness about these issues [33].

Based on the recent advancement in the industry and research, the following main areas of smart construction can be identified:

- Smart construction site environment (automation of construction site, GIS/GPS, radio-frequency identification (RFID), sensors, IoT, telematics, cameras, photogrammetry, and object recognition); 
- Smart communication and data management (integration of environmental, quality, safety, logistics, progress information);

- Smart construction technologies and project management (off-site construction (modules), 3D printing, 3D scanning, lasers, GPS technologies, smart construction machinery and equipment, robots, drones, building information modelling (BIM), VR, AR, digital twin, machine learning, artificial intelligence).

The requirements for smart building materials, services, and construction based on industry practices and the literature review are provided in Table 5.

Table 5. Requirements for smart building materials, services, and construction.

\begin{tabular}{|c|c|}
\hline \multicolumn{2}{|r|}{ Requirements for Smart Building Materials } \\
\hline Sustainability & $\begin{array}{l}\text { Material is evaluated according to eco-friendliness, secondary use, re-cycling } \\
\text { and, utilization, purchase and installation price, transportation, produced from } \\
\text { local resources }\end{array}$ \\
\hline $\begin{array}{l}\text { Adaptability to the } \\
\text { environment }\end{array}$ & $\begin{array}{l}\text { Ability to react and adapt to the environment by changing colour, form or } \\
\text { position, ability of self-protection and self-healing. }\end{array}$ \\
\hline $\begin{array}{l}\text { Information collection } \\
\text { and transmission }\end{array}$ & $\begin{array}{l}\text { Ability of the material to collect and transmit information in real time on } \\
\text { characteristics, loads, changes in environmental indicators }\end{array}$ \\
\hline \multicolumn{2}{|r|}{ Requirements for Smart Building Services } \\
\hline Sustainability & $\begin{array}{l}\text { Positive effects of the system on energy savings, environmental protection, local } \\
\text { economy and social well-being. }\end{array}$ \\
\hline $\begin{array}{l}\text { Adaptability to the } \\
\text { environment }\end{array}$ & $\begin{array}{l}\text { Sensors, mobile applications and wireless network are used for adaptation to } \\
\text { occupants needs and habits: adjustable lighting, pre-controlled microclimate, } \\
\text { controlled elevators, indoor mobility, etc. }\end{array}$ \\
\hline Renewable resources & $\begin{array}{l}\text { Use of renewable resources (solar, wind, water, geothermal) to generate } \\
\text { electricity, energy for cooling or heating; use of rain and flood water }\end{array}$ \\
\hline $\begin{array}{l}\text { Information collection } \\
\text { and transmission }\end{array}$ & Information is collected, analysed and transmitted to interested parties for use. \\
\hline \multicolumn{2}{|r|}{ Requirements for Smart Building Construction } \\
\hline Sustainability & $\begin{array}{l}\text { Peculiarities of logistics; duration, resources and costs of technological } \\
\text { processes; impact on local economy, human and environment, social welfare } \\
\text { of employees }\end{array}$ \\
\hline $\begin{array}{l}\text { Real-time information } \\
\text { communication }\end{array}$ & $\begin{array}{l}\text { Real-time information tracking and its communication to all } \\
\text { construction participants }\end{array}$ \\
\hline Information Management & $\begin{array}{l}\text { Building information modelling }(3 \mathrm{D}, 4 \mathrm{D}, 5 \mathrm{D}, 6 \mathrm{D}, 7 \mathrm{D}) \text {, risk management, } \\
\text { environmental, quality, safety and progress prediction and control. }\end{array}$ \\
\hline
\end{tabular}

The vision of the future construction site, modelling scenarios of the future construction worker, smart supply chain, smart plant operation, and smart real-time safety management systems were all presented in the research study by Edirisinghe [34]. The main aspects of the construction site digital skin, such as communication technologies, hardware, and middleware/software, were presented. The research analysed recent technology applications for construction, namely BIM-based visualisation, augmented reality, supply chain, labour, mobile equipment tracking, schedule and progress monitoring and safety management. However, these promising technologies can be brought to the construction sector through systematic procedures for standardisation and validation.

\subsection{Smart City Technologies}

Smart buildings in most cases can be built as stand-alone entities and operate independently from the outside urban world. However, the concept of a smart city emphasises the interconnectivity between the different layers of the city ecosystem, the share of information and the efficient resource usage. Thus, most ICT benefits might be achieved when the smart building is connected to a city 
information and management platform in order to share the input and output resources with other surrounding units [35].

The scientific community has already identified various technologies and ICT architecture models for smart cities. Park et al. [36] analysed the future sustainable smart energy city (SSEC) and identified the following elements as its integral parts: smart energy, smart energy data analytics, energy prosumer, energy security, and renewable energy. The authors specified that, for SSEC realisation, the identified elements have to be linked intelligently, and they presented an AI-based physical and virtual platform by applying a five-layer architecture to develop a SSEC:

- The first layer as the digital layer: data-based collection-transmission and analysis technology;

- The second layer as the home and buildings layer: smart homes, buildings, and factories;

- The third layer as the mobility layer: electric vehicles and smart mobility;

- The fourth layer as the infrastructure layer: sensors, actuators, network infrastructure, and energy grid;

- The fifth layer as the virtual layer: energy optimization technology through simulation based on augmented reality/virtual reality (AR/VR) and digital twin technology.

Lu et al. [37] developed the technology roadmap for building a smart city. The authors recommend arranging all smart city technologies and applications into four ascending ICT layers:

- Sensor level-biometric and environmental sensors, online video surveillance, recognition and testing, GPS, as well as energy, water, and power and monitoring;

- Integration level—heterogeneous network integration, IoT integration development platform, sensor integration, cyber-physical system (CPS)-based application services;

- Intelligent level-Big Data analysis, cloud computing services, intelligent grid;

- Application level—connecting and extending the previously listed layers into a wide range of smart applications.

Sodhro et al. [9] analysed how IoT technology might be implemented and sensor-enabled IoT devices might be integrated into a smart city ICT platform. The authors proposed an IoT-based smart city architecture model, which has a structure that is quite similar to that identified by Lu et al. [37]

- $\quad$ Layer 1-sensor networks, applications, services, tools;

- Layer 2-sensing, acquisition, and collection of data;

- Layer 3-data processing and monitoring;

- $\quad$ Layer 4-data integration and management;

- $\quad$ Layer 5-secure deployment and quality control.

The above section gave a review of the latest state of development of a smart city and a reference for the city administration to define the specific development strategy. The owners/developers of smart buildings need to define their strategy by answering the following questions: how can particular smart building applications contribute to smart city development, and what benefits might be achieved from this integration?

Common peculiarities of smart buildings and smart cities are smart technologies, sustainability, information management, real-time systems, renewable resources, and energy management. However, not all EU countries and cities are smart-ready built environments prepared for an increasing share of smart buildings in terms of dynamic operability, renewable energy uptake, energy-system responsiveness, or dynamic and self-learning control systems [38]. On the other hand, not all smart buildings are ready to perform as a part of a smart city network. Moreover, not every smart building can utilise most of the possible potential of a smart city and vice versa. Therefore, the authors propose an evaluation system that analyses a particular smart building in a particular smart city and calculates the potential of a smart building based on the smart system capabilities of a particular city. 


\subsection{SBISC Evaluation Framework}

This section provides the development methodology of a framework which enables users to evaluate a smart building's capability to interact at certain ICT layers of a Smart City digital platform and to define how the particular smart building applications are related with the particular smart city ecosystem. The Smart Building Integration in a Smart City (SBISC) evaluation framework was developed based on building performance, connectivity, communication, and integration level into a smart city system. Five smart city domains were selected as interrelated to the smart building and smart city: smart energy, smart mobility, smart life, smart environment, and smart data (Table 6). The domains were selected based on the analysis of different existing classifications and taking into account the major interconnectivity aspects between smart building and smart city digital platforms. The description of each domain is provided in Table 6. All these domains can be monitored and managed very effectively if all built environment elements are interconnected into one city-level ICT network [35]. Thus, the smart building performance score in each domain of the smart city is based on the smart building integration level into the smart city ICT platform (Table 7). The integration levels were adopted from the research study presented by Bernstein in 2014 [39], where the open system intelligence was described in detail from the interconnection point of view. Furthermore, this approach proves high correspondence to the logic of the recently proposed ICT architecture of smart city $[9,36]$ reviewed in Section 3.2.

Table 6. Description of smart building-smart city integration by smart city domains.

\begin{tabular}{ll}
\hline Smart City Domain & \multicolumn{1}{c}{ Description } \\
\hline Smart Energy & $\begin{array}{l}\text { Response to real-time power changes when connected to the grids. Information } \\
\text { collection, analysis, comparison, and recall from previous developments; justifying } \\
\text { decision-making and control to ensure the most effective performance. }\end{array}$ \\
\hline Smart Mobility & $\begin{array}{l}\text { Acquisition of real-time information from surrounding participants about their } \\
\text { mobility and needs. Connection to the networks facilitates efficient logistics and } \\
\text { infrastructure, considering past problems, addressing them in accordance with } \\
\text { reasonable trends and development strategies. }\end{array}$ \\
\hline Smart Life & $\begin{array}{l}\text { Disaster prediction, security, health, comfort, and quality assurance, whether automatic } \\
\text { or online, with the ability to store, analyse, compare data, and make informed decisions. }\end{array}$ \\
\hline Smart Environment & $\begin{array}{l}\text { Observation, analysis, and adaptation to the external environment and the ability to } \\
\text { receive information from influential actors and institutions. Online comparison and } \\
\text { management of renewable resources, recyclable materials, waste, and justification of } \\
\text { decisions based on past/previous reports. }\end{array}$ \\
\hline Smart Data & $\begin{array}{l}\text { Combination of collected data by analysis, comparison and justification. Reports and } \\
\text { communication of combined data to different actors responsible for remote control. }\end{array}$ \\
\hline
\end{tabular}

The smart building applications depend on construction technologies, i.e., the combined impact of smart materials, building services, and construction processes. The detailed description of how smart building components might be integrated within the different applications of smart city domains is provided in Table 8.

The conceptual model of Smart Building Integration into a Smart City (SBISC) framework, representing the case of ideal smart building and ideal smart city is provided Table 9 . The proposed evaluation framework indicates how the selected smart building integrates within the specific smart city ecosystem domains of smart energy, smart mobility, smart life, smart environment, and smart data. The maximum score is eight points for each domain, and the value of each smart building integration level is equal to 1 point. The levels are presented in priority order. To reach a higher level, all the lower levels have to be fulfilled. Based on the characteristics of the city, some domains of a specific smart city might be more developed than the others; thus, the project total evaluation and projected potential for improvement does not always reach the maximum scale of eight in every domain. 
Table 7. Smart building integration levels into a smart city information and communication technology (ICT) platform [39].

\begin{tabular}{|c|c|c|}
\hline & Smart Building Integration Levels & Level Description \\
\hline Level 1 & Ability to network (system and subsystem) & Connection to a wired or wireless network \\
\hline Level 2 & Ability to see information (real time) & $\begin{array}{l}\text { Response to any change in the environment or } \\
\text { traction of the amount of a given data stream }\end{array}$ \\
\hline Level 3 & Ability to collect information (historical) & $\begin{array}{l}\text { Collection of information with the potential to } \\
\text { share or use it in the future }\end{array}$ \\
\hline Level 4 & Ability to process information (analyse) & $\begin{array}{l}\text { Analysis of information received for the } \\
\text { appropriate actions }\end{array}$ \\
\hline Level 5 & Ability to make decisions (report); & $\begin{array}{l}\text { Evaluation of the resulting analysis and report } \\
\text { on changes }\end{array}$ \\
\hline Level 6 & Ability to compare baseline (evaluate) & Conclusion based on analysis over a period of time \\
\hline Level 7 & Ability to validate over time (trend) & $\begin{array}{l}\text { Introduction to trends, technological development, } \\
\text { continuous and reliable improvement }\end{array}$ \\
\hline Level 8 & Ability to control (act) & Autonomous decision-making and remote control \\
\hline
\end{tabular}

Table 8. Smart building application examples in relation to smart city domains.

\begin{tabular}{|c|c|c|c|c|c|}
\hline \multirow{2}{*}{$\begin{array}{l}\text { Smart } \\
\text { Building } \\
\text { Technologies }\end{array}$} & \multicolumn{5}{|c|}{ SMART CITY DOMAINS } \\
\hline & SMART ENERGY & $\begin{array}{c}\text { SMART } \\
\text { MOBILITY }\end{array}$ & SMART LIFE & $\begin{array}{c}\text { SMART } \\
\text { ENVIRONMENT }\end{array}$ & SMART DATA \\
\hline $\begin{array}{l}\text { Smart } \\
\text { Building } \\
\text { Services }\end{array}$ & $\begin{array}{l}\text { Connection to smart } \\
\text { energy grids. Sensors. } \\
\text { Automated control } \\
\text { systems. }\end{array}$ & $\begin{array}{l}\text { Wireless power } \\
\text { transmission. }\end{array}$ & $\begin{array}{l}\text { Video surveillance, } \\
\text { recognition } \\
\text { systems. Water } \\
\text { quality, waste } \\
\text { disposition } \\
\text { tracking. }\end{array}$ & $\begin{array}{l}\text { Water collection, } \\
\text { filtration, and secondary } \\
\text { use. Natural airflow } \\
\text { control. Renewable } \\
\text { sources. }\end{array}$ & $\begin{array}{c}\text { Information } \\
\text { transmission through } \\
\text { wired and wireless } \\
\text { networks. }\end{array}$ \\
\hline
\end{tabular}

The SBISC evaluation framework presents a novel approach combining smart building and smart city interoperability aspects. Smart city and smart building concepts and assessment schemes has been thoroughly analysed from different aspects in the state of the art review provided in the previous sections of this study. The smart building was researched with regards to its capability to automatically adjust and control the operation parameters. The research was realigned with the smart city ICT platform architecture, which is considered a new research trend started very recently. Thus, the SBISC framework fills the gap, disclosing the interoperability capabilities between the smart building and the external world/smart city digital platform, emphasizing the future trends of artificial intelligence in smart building and smart city management. 
Table 9. Smart Building Integration into a Smart City (SBISC) framework.

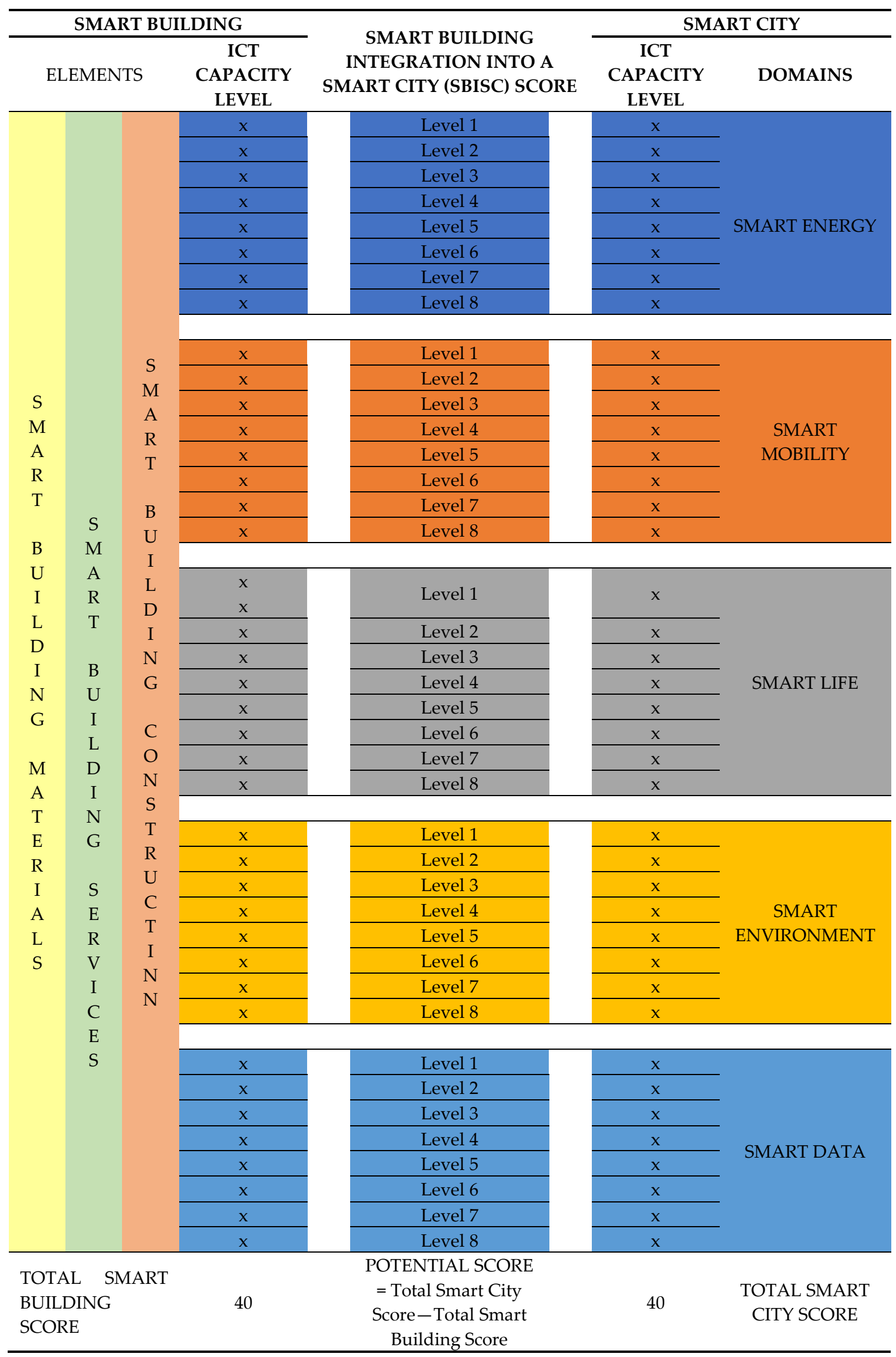




\section{Research on Smart Buildings Integration into Smart Cities}

\subsection{Research Methodology and Data}

In order to validate the proposed scheme, nine office buildings representing the smart building concept in different smart cities built within the period 2007-2018 with the total area from 10,000 $\mathrm{m}^{2}$ to $143,000 \mathrm{~m}^{2}$ were selected for the analysis (Table 10). The research data was gathered from various resources: project websites, research studies, projects analysis, etc. The majority of the projects were assessed by BREEAM New Construction, or LEED Core and Shell, but four of the nine selected projects were in parallel rated by local building sustainability assessment (BSA) schemes Since Sustainability aspects are integral part of a smart building, BSA attribute was important for project selection. The project set under the investigation represents three continents: Europe (4), North America (3), and Asia (2). The designated smart cities were evaluated as high (2), relatively high (4), medium (1), and low (1) performance levels based on the IESE Cities in Motion Index (CIMI). The CIMI is a composite index that assesses the development level of worldwide cities, The CIMI methodology is based on the evaluation of the following nine domains: human capital, social cohesion, economy, governance, environment, mobility and transportation, urban planning, international outreach, and technology [40].

Table 10. Overview of the projects.

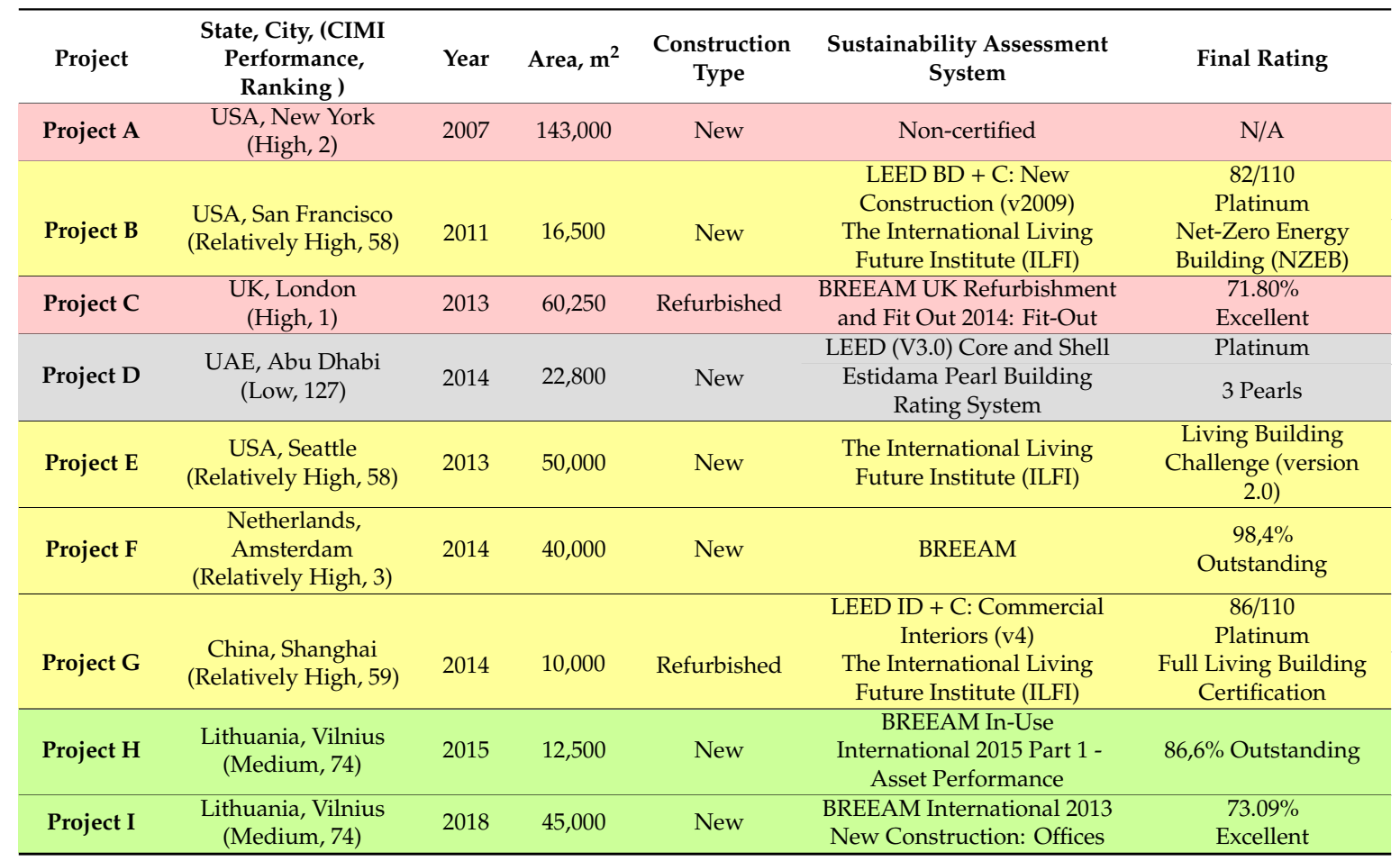

Each of the selected projects was assessed with the SBISC framework presented in the previous section; thus, the smart city capabilities were explored and evaluated in parallel with the projects. The examples of Smart City I and Smart Building I analysis are presented in Tables 11 and 12, respectively. Results of Smart Building I Integration in Smart City I are summarized in Table 13, which represents the results of ICT capacity level identified for smart building and for smart city. The given results were obtained using Table 9, which has been filled based on information provided in Table 11 for the smart city section and Table 12 for smart building section. 
Table 11. Analysis of Smart City I [41,42].

\begin{tabular}{|c|c|c|c|c|c|}
\hline $\begin{array}{l}\text { SMART } \\
\text { CITY }\end{array}$ & $\begin{array}{l}\text { SMART } \\
\text { ENERGY }\end{array}$ & SMART MOBILITY & SMART LIFE & SMART ENVIRONMENT & SMART DATA \\
\hline CITY I & $\begin{array}{l}60 \% \text { of energy } \\
\text { from biofuel } \\
\text { and biomass. } \\
\text { High efficiency } \\
\text { LED street } \\
\text { lighting } \\
\text { reduced } 70 \% \text { of } \\
\text { power } \\
\text { consumption. }\end{array}$ & $\begin{array}{l}\text { The city promotes car } \\
\text { sharing and public } \\
\text { transport: redesigned } \\
\text { public transport routes, } \\
\text { express bus lines. Traffic } \\
\text { monitoring and control } \\
\text { system combines all } \\
\text { traffic lights across the } \\
\text { city into one centrally } \\
\text { managed network. } \\
\text { Two mobile applications: } \\
\text { mTicket and m.Parking. } \\
\text { m.Ticket allows } \\
\text { purchasing public } \\
\text { transport tickets on the } \\
\text { phone, and the } \\
\text { monitoring of the } \\
\text { movement of buses and } \\
\text { the planning of trips. } \\
\text { m.Parking is a solution } \\
\text { for paying for parking } \\
\text { on a smart phone. } \\
\text { Mobile platform "Trafi" } \\
\text { for trip planning: access } \\
\text { to traffic data and } \\
\text { timetable of public } \\
\text { transportation, parking } \\
\text { location and exact price. }\end{array}$ & $\begin{array}{l}\text { Smart management - } \\
\text { electronic platforms } \\
\text { for communication } \\
\text { with city } \\
\text { administration } \\
\text { engage citizens and } \\
\text { business in } \\
\text { decision-making. } \\
\text { Mobile app "Tvarkau } \\
\text { Miesta - Maintain } \\
\text { City"), enables the } \\
\text { residents to report } \\
\text { overflowing bins or } \\
\text { objects blocking } \\
\text { public roads, etc. The } \\
\text { mobile application } \\
\text { was developed to } \\
\text { foster the direct } \\
\text { communication } \\
\text { between the } \\
\text { residents and the } \\
\text { municipality. }\end{array}$ & $\begin{array}{l}\text { The city provides one of the } \\
\text { fastest public Wi-Fi internet } \\
\text { connection in the world } \\
\text { (2018), a high quality of life, } \\
\text { clean water and fresh air. } \\
\text { IoT technology is used for } \\
\text { the following applications: } \\
\text { lighting, traffic, air pollution, } \\
\text { agriculture, healthcare, retail } \\
\text { and logistics. } \\
\text { Fast development of smart } \\
\text { technology areas within the } \\
\text { city: financial technology, IT } \\
\text { (games, cyber security, data } \\
\text { centres), biotechnology, } \\
\text { electronics and optical } \\
\text { systems. } \\
\text { Five official sandboxes were } \\
\text { open - three in fintech, as } \\
\text { well as an energy and } \\
\text { proptech. Proptech sandbox } \\
\text { "Realbox" gives start-ups the } \\
\text { possibility to test their } \\
\text { products within } 2.5 \text { million } \\
\text { m² of commercial, } \\
\text { residential and } \\
\text { multi-purpose buildings. }\end{array}$ & $\begin{array}{l}\text { LoRa wireless } \\
\text { technology } \\
\text { supports low data } \\
\text { rate } \\
\text { communications } \\
\text { over long distances } \\
\text { by sensors and } \\
\text { actuators for M2M } \\
\text { and Internet of } \\
\text { Things (IoT) } \\
\text { applications. } \\
\text { The city } \\
\text { municipality } \\
\text { provides free } \\
\text { access to financial, } \\
\text { public } \\
\text { procurement, real } \\
\text { estate, transport } \\
\text { and other open } \\
\text { data. }\end{array}$ \\
\hline
\end{tabular}

Table 12. Analysis of Smart Building I [43].

\begin{tabular}{|c|c|c|c|c|c|}
\hline $\begin{array}{l}\text { SMART } \\
\text { BUILDING I }\end{array}$ & SMART ENERGY & SMART MOBILITY & SMART LIFE & $\begin{array}{l}\text { SMART } \\
\text { ENVIRONMENT }\end{array}$ & SMART DATA \\
\hline $\begin{array}{l}\text { Project ISmart } \\
\text { Construction }\end{array}$ & $\begin{array}{l}\text { A Class Energy } \\
\text { Performance Certificate. }\end{array}$ & $\begin{array}{l}\text { New street section, } \\
500 \text { m bicycle route } \\
\text { was connected to the } \\
\text { existing } \\
\text { infrastructure and } \\
\text { new } 3 \text { level } \\
\text { underground } \\
\text { parking. New } \\
\text { pedestrian } \\
\text { connections were } \\
\text { formed. New traffic } \\
\text { lights installed. } \\
\text { Bicycle storage } \\
\text { facilities. }\end{array}$ & $\begin{array}{l}\text { Office spaces are } \\
\text { easy to redesign to } \\
\text { meet the business } \\
\text { needs. The } \\
\text { complex also } \\
\text { includes social } \\
\text { spaces and services: } \\
\text { a dining room, } \\
\text { conference, gym, } \\
\text { games room, } \\
\text { library and } \\
\text { lounges. }\end{array}$ & $\begin{array}{l}\text { BREEAM New } \\
\text { Construction (Excellent). } \\
\text { The combined } \\
\text { courtyards of the } \\
\text { buildings form public } \\
\text { spaces - a harmonious } \\
\text { and attractive } \\
\text { environment for city } \\
\text { residents and guests. As } \\
\text { much natural light as } \\
\text { possible for every } \\
\text { workstation illumination. } \\
\text { Facilities for waste } \\
\text { sorting. }\end{array}$ & $\begin{array}{l}\text { Smart application } \\
\text { platform to capture, } \\
\text { assign and monitor } \\
\text { construction } \\
\text { defects repair. An } \\
\text { automated } \\
\text { streaming ordering } \\
\text { and delivery } \\
\text { system for building } \\
\text { materials. An } \\
\text { hourly delivery } \\
\text { schedule enabled } \\
12 \% \text { more efficient } \\
\text { results. }\end{array}$ \\
\hline $\begin{array}{l}\text { Smart } \\
\text { Building } \\
\text { Materials }\end{array}$ & $\begin{array}{l}\text { Wide application of } \\
\text { renewable energy } \\
\text { sources: } 10 \% \text { of } \\
\text { electricity from } \\
\text { photovoltaic (PV) solar } \\
\text { panels; water in the } \\
\text { building is heated by } \\
\text { solar panels; buildings } \\
\text { are centrally heated by } \\
\text { air-water heat pumps. }\end{array}$ & $\begin{array}{l}\text { Atypical elevator } \\
\text { design. Both } \\
\text { panoramic and cargo } \\
\text { elevators were } \\
\text { adapted to the } \\
\text { interior solutions of } \\
\text { the building. }\end{array}$ & $\begin{array}{l}\text { Double facade } \\
\text { (four glass layers) } \\
\text { with external } \\
\text { louvers is installed } \\
\text { to protect against } \\
\text { excessive heat and } \\
\text { glares. External } \\
\text { blinds controlled } \\
\text { automatically. }\end{array}$ & $\begin{array}{l}\text { Responsibly produced } \\
\text { and healthy materials } \\
\text { were used for } \\
\text { construction. } 85 \% \text { of the } \\
\text { construction waste was } \\
\text { recycled or reused.The } \\
\text { white colour of the } \\
\text { facade and the light roof } \\
\text { help to save energy for } \\
\text { cooling. }\end{array}$ & \\
\hline $\begin{array}{l}\text { Smart } \\
\text { Building } \\
\text { Services }\end{array}$ & $\begin{array}{l}\text { Integrated } \\
\text { state-of-the-art } \\
\text { engineering systems, } \\
\text { building management } \\
\text { system installed. } \\
\text { Complex } \\
\text { heating-cooling system } \\
\text { consists of and } \\
\text { interconnected air-water } \\
\text { heat pumps, chillers, } \\
\text { variable refrigerant } \\
\text { volume (VRV) systems, } \\
\text { solar collectors and city } \\
\text { heating networks. }\end{array}$ & $\begin{array}{l}\text { Elevators designed } \\
\text { with a focus on } \\
\text { functionality - their } \\
\text { vertical speeds meet } \\
\text { the highest } \\
\text { standards. Electric } \\
\text { car charging stations. }\end{array}$ & $\begin{array}{l}\text { Digital room } \\
\text { reservation system, } \\
\text { flexible access } \\
\text { control, easy } \\
\text { transformation of } \\
\text { interior partitions } \\
\text { and redesign of } \\
\text { desired spaces. } \\
\text { Performance } \\
\text { parameters } \\
\text { management of } \\
\text { building } \\
\text { spaces/rooms with } \\
\text { PC tablets. }\end{array}$ & $\begin{array}{l}\text { Building management } \\
\text { system for integrated } \\
\text { state-of-the-art } \\
\text { engineering systems } \\
\text { control: security alarm, } \\
\text { access control, video } \\
\text { surveillance system, etc. } \\
\text { Automatic lighting, } \\
\text { humidity control. } \\
\text { Water-saving technology } \\
\text { appliances. Rainwater } \\
\text { utilization. }\end{array}$ & $\begin{array}{l}\text { Ventilation control } \\
\text { based on } \mathrm{CO}_{2} \\
\text { concentration. }\end{array}$ \\
\hline
\end{tabular}


Table 13. Evaluation results of Smart Building (SB) I Integration into Smart City (SC) I.

\begin{tabular}{|c|c|c|c|c|c|c|c|c|c|c|}
\hline \multirow[t]{2}{*}{ Integration Level (1 Point Each) } & \multicolumn{2}{|c|}{$\begin{array}{l}\text { Smart } \\
\text { Energy }\end{array}$} & \multicolumn{2}{|c|}{$\begin{array}{l}\text { Smart } \\
\text { Mobility }\end{array}$} & \multicolumn{2}{|c|}{$\begin{array}{c}\text { Smart } \\
\text { Life }\end{array}$} & \multicolumn{2}{|c|}{$\begin{array}{c}\text { Smart } \\
\text { Environment }\end{array}$} & \multicolumn{2}{|c|}{ Smart Data } \\
\hline & SB & SC & SB & SC & SB & SC & SB & SC & SB & SC \\
\hline $\begin{array}{l}\text { Ability to network } \\
\text { (system and subsystem) }\end{array}$ & 1 & 1 & 1 & 1 & 1 & 1 & 1 & 1 & 0 & 0 \\
\hline Ability to collect information (historical) & 1 & 1 & 1 & 1 & 1 & 1 & 1 & 1 & 0 & 0 \\
\hline Ability to see information (real time) & 1 & 1 & 1 & 1 & 1 & 1 & 1 & 1 & 0 & 0 \\
\hline Ability to process information (analyse) & 1 & 1 & 1 & 1 & 1 & 1 & 1 & 1 & 0 & 0 \\
\hline Ability to make decisions (report) & 1 & 1 & 1 & 1 & 1 & 1 & 1 & 1 & 0 & 0 \\
\hline Ability to compare (baseline evaluate) & 0 & 1 & 1 & 1 & 1 & 1 & 1 & 1 & 0 & 0 \\
\hline $\begin{array}{l}\text { Ability to validate } \\
\text { over time (trend) }\end{array}$ & 0 & 1 & 1 & 1 & 0 & 1 & 0 & 1 & 0 & 0 \\
\hline $\begin{array}{l}\text { Ability to control } \\
\text { (take action) }\end{array}$ & 0 & 1 & 0 & 0 & 0 & 1 & 0 & 1 & 0 & 0 \\
\hline TOTAL SCORE: & 5 & 8 & 7 & 7 & 6 & 8 & 6 & 8 & 0 & 0 \\
\hline POTENTIAL SCORE: & \multicolumn{2}{|c|}{+3} & \multicolumn{2}{|c|}{+0} & \multicolumn{2}{|c|}{+2} & \multicolumn{2}{|c|}{+2} & \multicolumn{2}{|c|}{+0} \\
\hline
\end{tabular}

The summarized SBISC assessment results are presented in Table 14. The average score of smart building integration in smart city is 18.56 , with the lowest score of nine and the highest of 31 . Only an ideal smart building project in an ideal smart city would reach the score of 40 points, so 35 is a very high result (Figure 1). The average potential score of 7.44 means that the average city capacity to interconnect the smart building is higher than that which is actually employed. If the average smart building integration into the smart city platform was increased by potential average score provided with the average city, it would result in 26 final points, which is above the half of the ideal score.

Table 14. Summarized SBICSC assessment results.

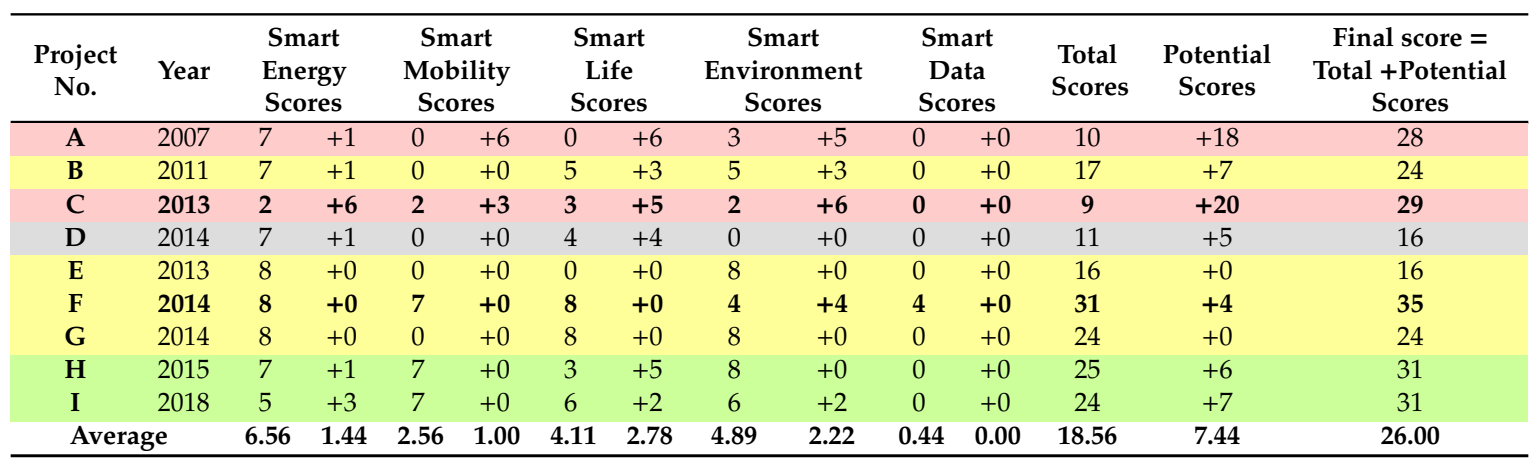

\subsection{Results and Discussions}

Looking from the different smart city perspectives, the priority list of smart city domains contributed by smart buildings for the analysed project set might be defined as smart energy $(35 \%)$, smart environment $(26 \%)$, smart life (22\%), smart mobility $(14 \%)$, and smart data $(3 \%)$. The leading position of the smart energy domain could be explained by strategic priority being assigned to the energy sector $[3,22]$. The high results demonstrated by the smart environment domain is related to the recent tendencies of environmental awareness and buildings sustainability assessment. The smart life domain represents a new-generation technology-based lifestyle supported by sophisticated building automation and managements systems, which are inspired by the Industry 4.0 revolution. The smart life and smart environment domains demonstrated the best potential to grow in the future $(-37 \%$ and $30 \%$ ), since the recent strategies of smart cities development are very much oriented toward these directions. The smart mobility and smart data domains so far are underused within the analysed smart building projects. However, the potential of those two domains are supposed to be boosted in the near future due to increasing artificial intelligence and smart data employment at a city level and 
virtual reality, augmented reality, BIM, digital twins, and other technology applications within the construction sector.

PROJECT TOTAL AND POTENTIAL SCORES

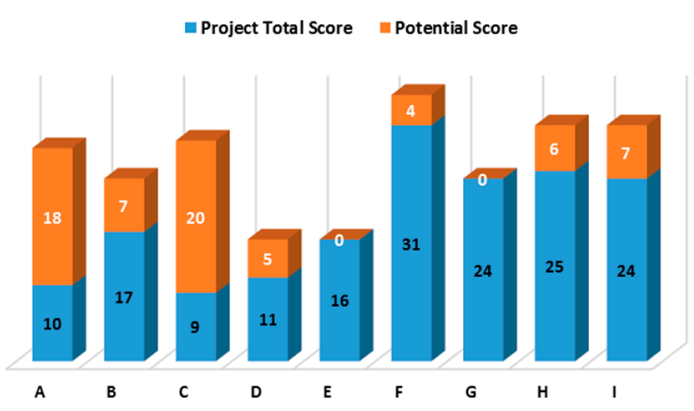

Average Project Score

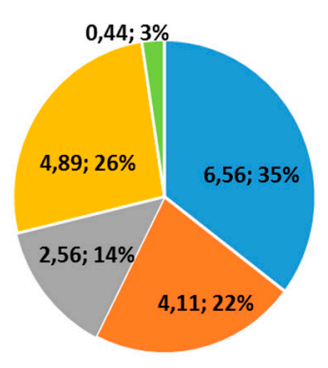

MIN, AVERAGE and MAX PROJECT SCORES

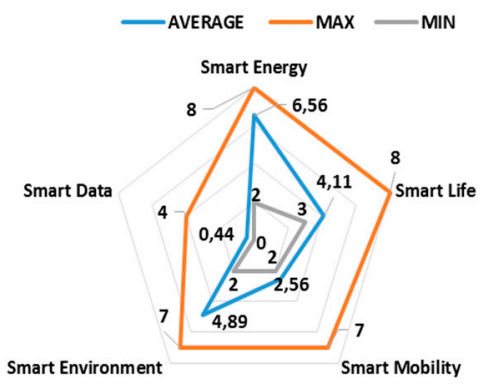

Average Potential Score

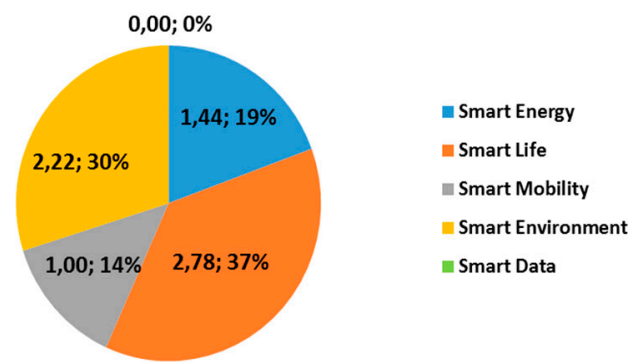

Figure 1. Overview of the project scores.

Figure 2 presents the different projects integration into different smart cities examples. Project D was built in the lowest CIMI score city, where the ICT integration was possible only within Smart Energy and Smart Life domains. The ICT capacity of Project E exactly corresponds with the ICT capacity level of the city. Spider graphs of Project $F$ and Project $C$ correspondingly illustrate the best and the lowest results within the analysed smart buildings. Both of the projects were built in the high-performance smart cities; however, the construction type and time were significantly different. Projects $\mathrm{H}$ and I were built in the same city and had identical final scores, but their integration profiles into the smart city domains are quite different. It must be noted that not every city has the smart ready environment of the highest level in every single domain, so if the building has a higher ICT capacity/level, this functionality might be underused for a while, until the city employs it. However, there are more common cases in which the functionality level of the city over the time becomes higher that the potential of the smart building itself. In this case, the potential points were assigned, and alternatives of additional investment into the smart functionality of the building might be recommended to the owners. In this way, the owners will be able to assess and compare their future smart building projects according to the capacity of a smart city.

When applying the SBISC framework to the new project cases, the selected smart building concept may be more sophisticated than the ICT platform of the city, as the owners expected or were aware of smart city development in the near future. According to the logic of the SBSCI framework, the deployed partial investments for the buildings' future technologies will not be effective until the city ICT capacity becomes prepared for the particular functionality. The additional score of +1 on the Smart Building ICT level would be neutralized by -1 on the Smart City ICT level. 

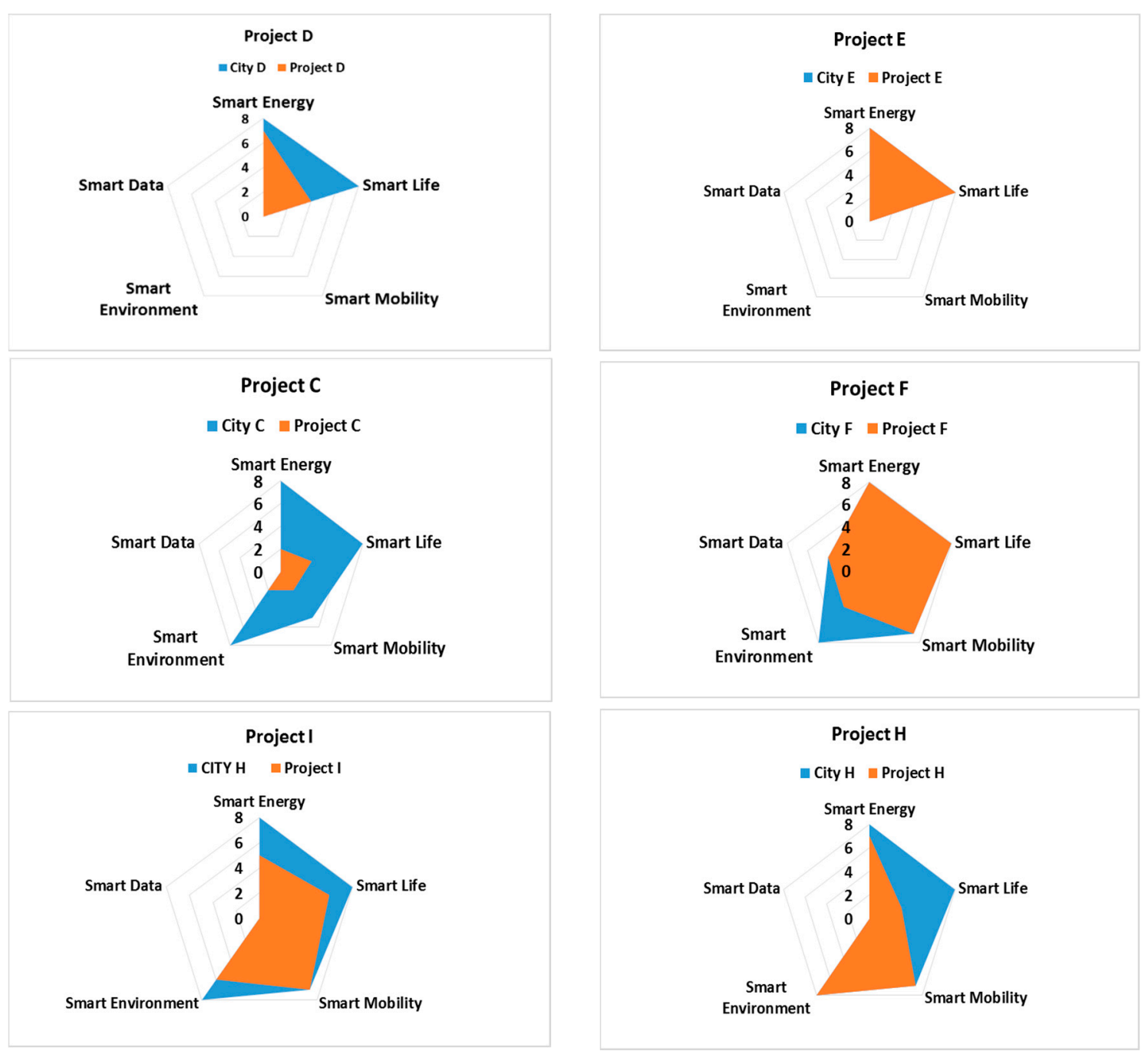

Figure 2. Sectional Analysis of Smart Buildings Integration into Smart Cities.

\section{Conclusions}

This study presented the Smart Building in a Smart City (SBISC) evaluation framework, which was developed based on the building performance compatibility level of smart buildings to a smart city digital platform. The analysis revealed that the most important issue for a smart building's full integration into a smart city platform is to employ all the functionalities proposed by the smart domains of the city in the smart building and vice versa by enabling the recommended features of smart materials, smart building services, and smart construction to serve the surrounding systems. Therefore, five smart city domains were selected as interrelated to the smart building and smart city concepts, taking into account the major interconnectivity aspects between smart building and smart city digital platforms: smart energy, smart mobility, smart life, smart environment, and smart data.

In this study, the proposed SBISC scheme was applied to nine smart buildings in eight different cities. The research of selected projects revealed that smart energy and smart environment are the most advanced domains in smart buildings integration into the smart city platform, representing $35 \%$ and $26 \%$ of integration capacity. According to the results, smart buildings have the highest interoperability potential by increasing integration capabilities by $37 \%$ and $30 \%$ in the domains of smart environment and smart life, respectively.

The proposed SBISC framework fills the gap, disclosing the interoperability capabilities between the smart building and the external world/smart city digital platform, emphasising the future trends of artificial intelligence in smart building and smart city management. The introduced evaluation 
methodology can serve as a framework for the owners, real estate developers, and contractors when building future intelligent buildings in smart cities. The investment decisions regarding future building technologies can considered to be worth the cost at the concept stage by the owners, or additional funds need to be allocated for building technologies upgrading in the near future if the city ICT platform enhancement is under the implementation of a strategic smart city development plan. The major challenge for real estate developers would be to realign the concept of the future smart building with the strategic development plans of the smart city.

The future research possibilities of Smart Building Integration into Smart City might be expanded by incorporating the interoperability and smart building performance forecasting based on the digital building and digital city modelling.

Author Contributions: Conceptualization, R.A.; methodology, R.A.; validation, P.A.F.; formal analysis, R.A. and P.A.F.; investigation, A.V.; resources, R.A., A.V., and P.A.F.; data curation, P.A.F.; writing—original draft preparation, A.V.; writing-review and editing, P.A.F.; visualization, R.A.; supervision, P.A.F.; project administration, P.A.F. All authors have read and agreed to the published version of the manuscript.

Funding: This research received no external funding.

Conflicts of Interest: The authors declare no conflict of interest.

\section{References}

1. UN. World Urbanization Prospects: The 2018 Revision; United Nations: New York, NY, YSA, 2018.

2. UN. Sustainable Cities: Why They Matter; United Nations: New York, NY, YSA, 2015.

3. Fokaides, P.A.; Polycarpou, K.; Kalogirou, S. The impact of the implementation of the European Energy Performance of Buildings Directive on the European building stock: The case of the Cyprus Land Development Corporation. Energy Policy 2017, 111, 1-8. [CrossRef]

4. European Committee for Standardization. Mapping of European Standards and Initiatives Relevant to Smart Cities. Available online: https://www.cencenelec.eu/standards/Sectorsold/SmartLiving/smartcities/Pages/ default.aspx (accessed on 21 February 2020).

5. Fokaides, P.A.; Apanaviciene, R.; Klumbyte, E. 5.12 Energy Management in Smart Cities. Compr. Energy Syst. 2018, 457-473. [CrossRef]

6. Kylili, A.; Fokaides, P.A. Competitive auction mechanisms for the promotion renewable energy technologies: The case of the $50 \mathrm{MW}$ photovoltaics projects in Cyprus. Renew. Sustain. Energy Rev. 2015, 42, $226-233$. [CrossRef]

7. Ghaffarianhoseini, A.; Berardi, U.; AlWaer, H.; Chang, S.; Halawa, E.; Ghaffarianhoseini, A.; Clements-Croome, D. What is an intelligent building? Analysis of recent interpretations from an international perspective. Archit. Sci. Rev. 2016, 59, 338-357. [CrossRef]

8. Albino, V.; Berardi, U.; Dangelico, R.M. Smart cities: Definitions, dimensions, performance, and initiatives. J. Urban Technol. 2015, 22, 3-21. [CrossRef]

9. Sodhro, A.H.; Pirbhulal, S.; Luo, Z.; de Albuquerque, V.; Hugo, C. Towards an optimal resource management for IoT based Green and sustainable smart cities. J. Clean. Prod. 2019, 220, 1167-1179. [CrossRef]

10. Camero, A.; Alba, E. Smart City and information technology: A review. Cities 2019, 93, 84-94. [CrossRef]

11. Appio, F.P.; Lima, M.; Paroutis, S. Understanding Smart Cities: Innovation ecosystems, technological advancements, and societal challenges. Technol. Forecast. Soc. Chang. 2019, 142, 1-14. [CrossRef]

12. Li, X.; Fong, P.S.W.; Dai, S.; Li, Y. Towards sustainable smart cities: An empirical comparative assessment and development pattern optimization in China. J. Clean. Prod. 2019, 215, 730-743. [CrossRef]

13. Giffender, R.; Fertner, C.; Kramar, H.; Kalasek, R.; Pichler-Milanović, N.; Meijers, E. Smart cities: Ranking of European Medium-Sized Cities; Vienna University of Technology: Vienna, Austria, 2007; p. 25.

14. Lombardi, P.; Giordano, S.; Farouh, H.; Yousef, W. Modelling the smart city performance. Innov. Eur. J. Soc. Sci. Res. 2012, 25, 137-149. [CrossRef]

15. Cohen, B. The 3 Generations of Smart Cities: Inside the Development of the Technology Driven City. Available online: https://www.fastcompany.com/3047795/the-3-generations-of-smart-cities (accessed on 22 September 2018). 
16. UNECE. The UNECE-ITU Smart Sustainable Cities Indicators; United Nations Economic Commission for Europe, United Nations: New York, NY, USA, 2015.

17. Fourtané, S. The Technologies Building the Smart Cities of the Future. Available online: https://interestingengineering.com/the-technologies-building-the-smart-cities-of-the-future (accessed on 12 December 2018).

18. UNEP. Energy Efficiency for Buildings; United Nations Environment Programme, United Nations: New York, NY, USA, 2009.

19. Buckman, A.H.; Mayfield, M.; Beck, S.B.M. What is a Smart Building? Smart Sustain. Built Environ. 2014, 3, 92-109. [CrossRef]

20. European Committee. ICT for a Low Carbon Economy Smart Buildings; European Commission: Brussels, Belgium, 2009.

21. Smart Building Market. 2018 Global Trends, Market Share, Industry Size, Growth, Opportunities and Forecast to 2023; Reuters: Canary Wharf, UK, 2018.

22. Fokaides, P.A.; Christoforou, E.A.; Kalogirou, S.A. Legislation driven scenarios based on recent construction advancements towards the achievement of nearly zero energy dwellings in the southern European country of Cyprus. Energy 2014, 66, 588-597. [CrossRef]

23. Fokaides, P.A.; Christoforou, E.; Ilic, M.; Papadopoulos, A. Performance of a Passive House under subtropical climatic conditions. Energy Build. 2016, 133, 14-31. [CrossRef]

24. Omar, O. Intelligent building, definitions, factors and evaluation criteria of selection. Alexandria Eng. J. 2018, 57, 2903-2910. [CrossRef]

25. Sharifi, A. A typology of smart city assessment tools and indicator sets. Sustain. Cities Soc. 2020, 53, 101936. [CrossRef]

26. Building Intelligence Quotient. Available online: http://www.building-iq.com/biq/index.html (accessed on 17 December 2018).

27. Honeywell and Ernst \& Young LLP. Smart Buildings Make Smart Cities. Honeywell Smart Building Score ${ }^{\mathrm{TM}}$; Green. Safe. Productive, Honeywell International Inc.: Gurgaon, India; Available online: https://smartbuildings. honeywell.com/hsbs_home (accessed on 12 December 2018).

28. Directive 2018/844 of the European Parliament and of the Council of 30 May 2018 amending Directive 2010/31/EU on the energy performance of buildings and Directive 2012/27/EU on energy efficiency. Off. J. Eur. Union 2018, 19, L 156/75-L 156/91.

29. VITO NV. Smart Readiness Indicator for Buildings. Available online: https://smartreadinessindicator.eu/. (accessed on 27 December 2018).

30. Märzinger, T.; Österreicher, D. Supporting the Smart Readiness Indicator-A Methodology to Integrate A Quantitative Assessment of the Load Shifting Potential of Smart Buildings. Energies 2019, 12, 1955. [CrossRef]

31. Janhunen, E.; Pulkka, L.; Säynäjoki, A.; Junnila, S. Applicability of the Smart Readiness Indicator for Cold Climate Countries. Buildings 2019, 9, 102. [CrossRef]

32. Smart Building Market Research Report-Global Forecast till 2025. Available online: https://www. marketresearchfuture.com/reports/smart-building-market-1860 (accessed on 14 February 2020).

33. To, W.M.; Lee, P.K.; Lam, K.H. Building professionals' intention to use smart and sustainable building technologies-An empirical study. PLoS ONE 2018, 13, e0201625. [CrossRef]

34. Edirisinghe, R. Digital skin of the construction site: Smart sensor technologies towards the future smart construction site. Eng. Constr. Archit. Manag. 2019, 26, 184-223. [CrossRef]

35. Ahuja, A. Integration of Nature and Technology for Smart Cities, 3rd ed.; Springer International Publishing: Basel, Switzerland, 2016; p. 390.

36. Park, S.; Lee, S.; Park, S.; Park, S. AI-Based Physical and Virtual Platform with 5-Layered Architecture for Sustainable Smart Energy City Development. Sustainability 2019, 11, 4479. [CrossRef]

37. Lu, H.; Chen, C.; Yu, H. Technology roadmap for building a smart city: An exploring study on methodology. Future Gener. Comput. Syst. 2019, 97, 727-742. [CrossRef]

38. Buildings Performance Institute Europe. Is Europe Ready for the Smart Buildings Revolution? Available online: http://bpie.eu/publication/is-europe-ready-for-the-smart-buildings-revolution/ (accessed on 28 December 2018).

39. Bernstein, R. Design and Specification of Open Systems. Available online: https://www.lonmark.org/ connection/presentations/2014/AHR/AHR2014_SpecDev.pdf (accessed on 7 May 2018). 
40. IESE Business School, University of Navarra. IESE Cities in Motion Index. Available online: https: //media.iese.edu/research/pdfs/ST-0509-E.pdf (accessed on 28 April 2019).

41. Loritz, M. Fintech Centre, Smart City, and Aspiring Proptech Hub, Vilnius aims to Turn Itself into a Giant Sandbox for Startups. Available online: https://www.eu-startups.com/2019/03/fintech-centre-smartcity-and-aspiring-proptech-hub-vilnius-aims-to-turn-itself-into-a-giant-sandbox-for-startups/ (accessed on 7 February 2020).

42. "Post Scriptum". Is Vilnius a Smart City? Available online: https://lithuaniatribune.com/is-vilnius-a-smartcity/ (accessed on 7 December 2019).

43. Meet S7. Available online: http://www.saltoniskiu7.1t/ (accessed on 7 February 2020).

C 2020 by the authors. Licensee MDPI, Basel, Switzerland. This article is an open access article distributed under the terms and conditions of the Creative Commons Attribution (CC BY) license (http://creativecommons.org/licenses/by/4.0/). 